\title{
RII: A New Index for Assessing Internationalization of Chinese Currency
}

\author{
Tu Yonghong, Dai Wensheng, Zhao Xueqing \\ International Monetary Institution, China Financial Policy Research Center, Renmin University of China, Beijing, China
}

\begin{abstract}
The diversified reform of the international currency system in the post-financial crisis era brought opportunities for the Internationalization of Chinese currency RMB. The year 2011 has seen a huge progress in the trade settlement and international financial transaction of RMB. However, an objective evaluation of the improvement in RMB internationalization is still difficult. Different from the index of the proportion of international reserve currency, this essay is to analyze the internationalization based on the pricing, trading and reserve functions of international currency. The innovation of this essay lies in the compilation principles of RII and the construction of index system. RII stood at 0.45 in 2011, indicating its preliminary recognition from the international community. But there is still great gap in the internationalization between RMB and other major currencies like US dollars, Euro.
\end{abstract}

Keywords: Internationalization of RMB; compilation principle of RII; construction of index system; RII model; application of RII

\section{Background of Compiling the RMB Internationalization index (RII)}

The 21st century has seen a rapid growth in Chinese economy, resulting from the benefit of economic globalization. China became the world's second largest economy in 2010 and is also the world's second-largest exporter. Given China's rapid economic growth and expansion in trade and investment, Dobson (2008), Eichengreen (2010), Kroeber (2011)argue that the moment has come for the internationalization of Renminbi and, naturally, advances towards this goal shall be progressed. The financial crisis in 2008 revealed the huge systemic risk in the international monetary system dominated by the US dollar and it has been a consensus of international society to diversify the reserve currency system in order to resolve inherent contradictions in the current system. Lee (2010) and Daokui Li (2010) believe the internationalization of Renminbi a vital direction for the reform of international monetary system and international financial stability.

In 2009, China started a pilot program to use RMB as the pricing and settlement currency in cross border trades. In 2011 China expanded the pilot domestic parties from the original 5 provinces to all over the country and the foreign parties from East Asian countries to the global market. Meanwhile, China started experimental use of RMB in cross border investments and financial transactions which were regarded a sign of deregulation

Tu Yonghong, International Monetary Institution, China Financial Policy Research Center, Renmin University of China, Beijing, China. Email: tuyh1966@ruc.edu.cn.

Dai Wensheng, International Monetary Institution, China Financial Policy Research Center, Renmin University of China, Beijing, China. Email: daiws@ruc.edu.cn.

Zhao Xueqing, International Monetary Institution, China Financial Policy Research Center, Renmin University of China, Beijing, China. Email: zhaoxueqing@vip.sina.com. 
in the capital account supervision. China signed the currency swap contracts with 14 countries and districts, reaching the scale of 1346.2 billion Yuan and 7 countries included RMB in their foreign exchange reserves. For this reason, Chen Yulu (2012) called 2011 as the starting year of RMB internationalization.

Undoubtedly, the internationalization of Renminbi is a long and winding process. How to perceive and grasp the degree of internationalization of Renminbi remains an unresolved problem. It is biased and inappropriate to infer the degree of internationalization of Renminbi simply by studying the proportion of the index of the international reserve currency, ignoring the transaction function of currencies. Thus, the purpose of this essay is to compile the index of Renminbi internationalization, providing a new indicator to reflect the performance of Renminbi functioning as an international currency dynamically. Through studying the level and changes of this index, the degree of internationalization of Renminbi can be determined clearly. Through horizontal and vertical comparison and analyses, the real acceptability of Renminbi from the international financial markets and the disparity between Renminbi and other major currencies can be discovered. In this way, valuable references can be provided for global trading and for choices of foreign reserves currencies.

\section{RII and its Compilation Principle}

\section{Compilation Principle of RII}

RMB internationalization index refers to the indicator and data that take global proportion of all functions of the RMB viewed as the international currency into consideration, providing an objective, dynamic, and scientific description of the degree of internationalization of the RMB.

Compilation of RII is based on the definition of currency internationalization. The definition of currency internationalization is first seen in Benjamin J. Cohen of "The Future of Sterling as an International Currency" in 1971. Based on the functions of a currency, he raised that the use range of a currency expands outside the issuing country for all sorts of purposes, the currency becomes international currency. Tavlas (1997) further pointed out that internationalization of a currency is the international use of a currency. The use of a currency internationally occurs whenever a national currency performs the functions of money - i.e., unit of account, medium of exchange, and store of value - in transactions to which the issuing country is not a party. Chen Yulu (2005) made it clear that internationalization of a currency is that the use of a currency goes beyond country boundary, which can be the functions of medium of exchange, unit of account, and store of value in international trade and capital flows.

Currency internationalization refers to a sovereign currency performing functions of currency, being widely used by other countries in international trade, international capital flows and foreign exchange reserves. From static view, currency internationalization describes the status and result of currency being used as an international currency, and from dynamic view, currency internationalization involves the whole process of becoming an international currency. According to the above definition of currency internationalization, we give the following definition of internationalization of the RMB. Internationalization of the RMB refers to the process of RMB performing functions of currency worldwide, becoming major pricing and settlement currency in trade, and becoming financial transaction currency, and governments' international reserve currency. Therefore, the compilation of RII should be based on the definition of currency internationalization, involve every function of this international currency, and reflect its degree of internationalization objectively. 


\section{Indicator System}

Theoretically, currency has three primary functions - as a unit of account, as a medium of exchange, and as a store of value. As in international trade, pricing currency is usually the settlement currency, and one of the purposes of compiling RMB internationalization index is to focus on reflecting the actual use of RMB in international economic activities. Therefore, this report will merge the function as a unit of account and as a medium of exchange together. The first-level indicators of RII consist of international pricing and payment function and international reserve function. These two categories of indicators are consistent with the two categories of international economic transactions defined in the Balance of Payments Manual issued by the International Monetary Fund (IMF). The first category reflects international pricing, clearing and settlement functions of the RMB, specifically including indicators of RMB being used in international trade and indicators of RMB being used in capital and financial transactions. The second category reflects function of the RMB as international reserve. (Figure 1)

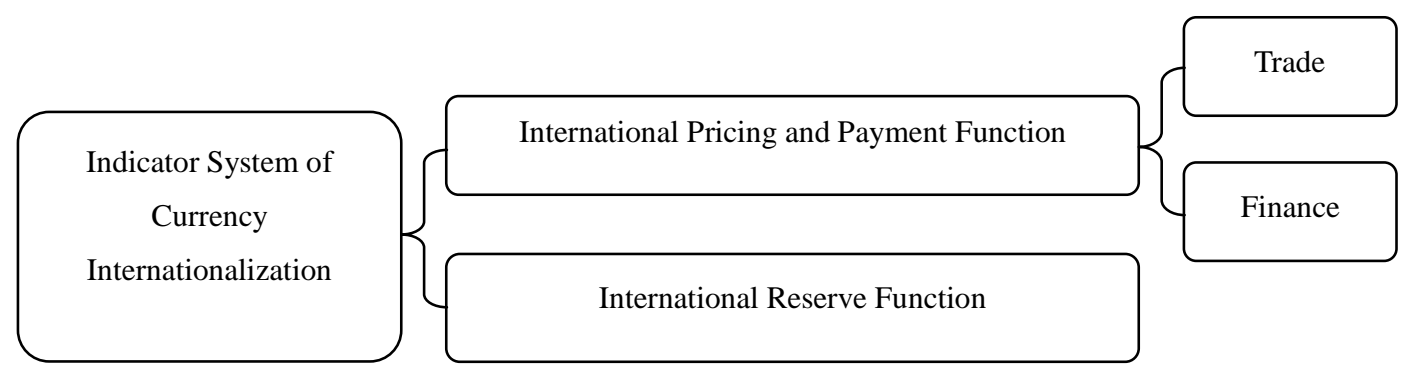

Figure 1. Indicator System of Rmb Internationalization Index

The international pricing and payment function of a currency consisting of trade and finance makes up the second-level indexes with international reserve function.

According to one of the principles in compiling RMB internationalization index, i.e., emphasizing the circulation and transaction functions of RMB in real economy, the functions of RMB in international trade should be the most important component in evaluating internationalization of the RMB. And we select the proportion of RMB settlement in world trade as the specific indicator.

According to the balance of payments, capital and financial accounts include all transactions between residents and non-residents, which include direct investment, international security and international credit. We have designed corresponding third-level indicators basing on functions of RMB in these three categories of transactions. (1) international credit: proportion of RMB credit in global foreign credit; (2) international securities: Proportion of RMB security in global issuance of international bonds and bills; (3) foreign direct investment: proportion of RMB direct investment in global foreign direct investment. And the following are some additional notes about indicators of securities. International security includes bond and stock. Because of great risk of information asymmetric in international finance, the scale of international bond market with fixed income is far larger than that of international stock, which has been always in dominant position in international security market. What's more, the scale of major national stock markets are often quoted in local currency, and they are lack of statistics on non-residents' stock investment different currencies. Therefore, taking financial theories and data availability into consideration, the international bonds and bills indicator of Bank for International Settlements (BIS) is used to reflect international security transactions. In order to reflect transactions of RMB international bonds more comprehensively and accurately, the indicator is further divided 
into two indicators. One is the stock indicator, namely, the remaining sum of outstanding bonds and bills. The other is the flow indicator, namely, the issuance amount of bonds and bills. The reason of doing this is that the stock indicator can objectively reflect the status quo of RMB in international bonds and bills transactions, and the flow indicator can better capture dynamic changes of RMB international bonds and bills. Certainly, accumulation of the flow results in the stock. And the relationship between these two indicators determines that the stock indicator itself involves the information of the flow indicator, thus we give a larger weight to the stock indicator of RMB international bonds and bills transactions.

The international reserve function is the most typical and centralized one among all international monetary functions. Generally, the proportion of a currency in foreign exchange reserves is the most immediate and intelligible indicator to measure its internationalization degree. So far, under the existing international monetary system, IMF only accounts the proportion of the dollar, the euro, the yen, the pound, the Swiss franc and other major currencies in official foreign exchange reserves. Since the scale of the RMB in official foreign exchange reserves is quite small, it is not accounted by IMF separately. In addition, for the sake of governments' own interests, majority of governments in the world normally do not publish specific currency structure of their official foreign exchange reserves, which leads to great difficulties in collecting data that reflects international reserve function of RMB. In fact, there are already nearly ten countries using RMB as one of their foreign exchange reserve currencies. With gradual improvement of our statistic system and deepening of international cooperation, the data availability of RMB as official reserve is expected to be improved.

Table 1

Indicator System of the RMB Internationalization Index

\begin{tabular}{|c|c|c|}
\hline First-level indicators & Second-level indicators & Third-level indicators \\
\hline \multirow{5}{*}{$\begin{array}{l}\text { International pricing and } \\
\text { payment function }\end{array}$} & & proportion of RMB settlement in world trade \\
\hline & \multirow{4}{*}{ Finance } & proportion of RMB credit in global foreign credit \\
\hline & & $\begin{array}{l}\text { proportion of RMB security in global issuance of international bonds and } \\
\text { bills }\end{array}$ \\
\hline & & $\begin{array}{l}\text { proportion of RMB security in global remaining sum of international bonds } \\
\text { and bills }\end{array}$ \\
\hline & & proportion of RMB direct investment in global foreign direct investment \\
\hline $\begin{array}{l}\text { International } \\
\text { function }\end{array}$ & $\begin{array}{l}\text { Official Foreign Exchange } \\
\text { Reserves }\end{array}$ & $\begin{array}{l}\text { proportion of RMB foreign exchange reserves in global foreign exchange } \\
\text { reserves }\end{array}$ \\
\hline \multicolumn{3}{|c|}{$\begin{array}{l}\text { proportion of RMB settlement in world trade=the amount of RMB cross-border trade / total value of world import and export } \\
\text { trade; } \\
\text { proportion of RMB credit in global foreign credit=the amount of RMB overseas credit/ the amount of global overseas credit; } \\
\text { proportion of RMB security in global issuance of international bonds and bills=the issuance of RMB international bonds and } \\
\text { bills/ the issuance of global international bonds and bills } \\
\text { proportion of RMB security in global remaining sum of international bonds and bills=the remaining sum of RMB international } \\
\text { bonds and bills/ the remaining sum of global international bonds and bills } \\
\text { proportion of RMB direct investment in global foreign direct investment=the amount of RMB direct investment/the amount of } \\
\text { global direct investment; } \\
\text { proportion of RMB foreign exchange reserves in global foreign exchange reserves=the remaining sum of RMB official exchange } \\
\text { reserves/ the remaining sum of global foreign exchange reserves }\end{array}$} \\
\hline
\end{tabular}

\section{The Compilation Method of RMB Internationalization Index}

\section{Index Methodology}

As the index methodology is concerned, RII has several calculation methods with their advantages and disadvantages respectively. One method is sum of the RMB's proportion in the world for each economic variables, the formula is 


$$
R I I=\sum_{j=1}^{5} X_{j t}
$$

The second is to set the global highest value as 100 and calculate the index with the benchmark of the global minimum value and global maximum value, the calculated formula is:

$$
R I I=\frac{\sum_{j=1}^{5}\left(X_{j t}-X_{j t \min }\right) W_{j}}{\sum_{j=1}^{5}\left(X_{j t \max }-X_{j t \min }\right) W_{j}}
$$

The third is weighted average of each variable:

$$
R I I=\frac{\sum_{j=1}^{5} X_{j t} W_{j}}{\sum_{j=1}^{5} W_{j}}
$$

Where $R_{t} I_{t}$ is the internationalization index, $X_{j t}$ is the value in time $t$ for the jth variable, $w_{j}$ is the weight for the jth variable, $X_{j t \max }$ is the global maximum value and $X_{j t \max }$ is the global minimum value in time $\mathrm{t}$ for $\mathrm{jth}$ variable. Because all variable is proportional value, it can be calculated directly.

The first method is simple and easy to understand, but the defect is with the same weight for different variable, so it can't reflect the emphasis of different function for the international monetary and can't reflect the international monetary policy guidance.

The second method can effectively measure the global position for local currency internationalization, but the index value for the monetary with highest internationalized degree is always 100, it cannot effectively respond to the position's change for different global internationalization monetary.

The third method can reflect not only the emphases function for international monetary (the more important the higher index weight) but the policy guidance with changing weight for different variables, and it can reflect the change of internationalization position for different monetary, so this paper uses the third kind of calculation method.

\section{The Source of data}

The detailed introductions of the sources of the data are showed in table 2.

Table 2

The Source of Internationalization Index of RMB and major currencies

\begin{tabular}{|l|l|}
\hline Indicator & Source of data \\
\hline proportion of RMB settlement in world trade & amount of RMB cross-border trade: PBC \\
\hline proportion of RMB credit in global foreign credit & total amount of the world import and export trade: IMF \\
\hline $\begin{array}{l}\text { proportion of bonds dominated in each currency in the issuance and } \\
\text { remaining sum of global international securities }\end{array}$ & Chinese RMB overseas loans : PBC; \\
\hline proportion of RMB direct investment in global direct investment & $\begin{array}{l}\text { RMB deposits in Hong Kong: Hong Kong Monetary } \\
\text { Authority; }\end{array}$ \\
\hline $\begin{array}{l}\text { proportion of foreign exchange reserves of each currencies in global } \\
\text { foreign exchange reserves }\end{array}$ & total amount of global foreign credit : BIS \\
\hline proportion of settlement of major currencies in world trade & BIS \\
\hline proportion of credit of major currencies in global foreign credit & $\begin{array}{l}\text { RMB foreign direct investment and overseas direct } \\
\text { investment: PBC, }\end{array}$ \\
\hline $\begin{array}{l}\text { proportion of direct investment of major currencies in global direct } \\
\text { investment }\end{array}$ & monetary policy executive reports, \\
\hline
\end{tabular}


The biggest difficulty in compiling the RMB internationalization index comes from limitation of data availability. Firstly, RMB is not an free convertibility currency due to incomplete openness of the capital account, and it is rarely used in international economic activities, thus global proportions of various indicators are negligible, e.g. the proportion of RMB in official foreign exchange reserves, and the proportion of RMB in international assets and liabilities of banking industries are both lower than 1\%. Consequently, major international financial institutions such as IMF and BIS attribute the data about RMB to "others" or "miscellaneous" other than treat it as a separate item when classifying indicators according to the international currency structure. In light of this, we can only sum up and estimate some indicators basing on existing information and data. Although these estimators are unavoidably different from their true values, we believe the indifference will not have significant influence on RMB international index. Moreover, with deepening of internationalization of the RMB, the data availability and quality of these indicators will be improved, thus these indicators will be kept in the index system. Secondly, there is no specific statistic on currency structure of some indicators. We carefully looked up websites and databases of several major international institutions(such as IMF, WB,WTO and so on), as well as those of major countries' national bureau of statistics, central banks and trade departments, and found that they generally did not have statistics on currency structure in trade settlement, direct investment, security investment, bank credit and so on. Despite Japan and the UK governments have released some reports which published the scale of different currencies used in trade; these reports were not released annually, but were results of irregular special surveys, which lacked continuity. Given the objective requirements of the RMB internationalization index, we give up those indicators which can reflect the internationalization degree of the currency but are unavailable, e.g. the global proportion of the scale of stock dominated in domestic currency. This report finally picks up six representative indicators to show the internationalization degree of the currency.

With the reform of international monetary system and elevation in the level of internationalization of the RMB, our group believes that statistics of future international finance will be improved, not only the currency structure data will be available, but also the data about RMB will be reported separately. Therefore, In the future, the indicator system of RMB internationalization index may more indicators and gets appropriately adjustment in weights of indicators along with improvement and refinement of statistics of international financial indicators.

RII Application: Interpret the process of RMB internationalization

Dynamic vertical analysis of RII

According to the above compilation methods of the RMB internationalization index, we calculated the RMB internationalization index from the first quarter in 2010 to the fourth quarter in $2011 .^{1}$

As figure 2 shows, the features of internationalization process of RMB are low basis and rapid growth. Since the start of RMB cross-border trade settlement in 2009, the process of internationalization of the RMB is only a short period of two years. Though the level of internationalization of the RMB is 0.45 , which shows the international use of the RMB is still very low, and its functions of international currency is negligible, it also indicates that internationalization of the RMB has successfully achieved the breakthrough. In 2010, the RMB internationalization index appeared a sharp increase, meaning that internationalization of the RMB develops

\footnotetext{
1 The RMB settlement of cross-border trades, RMB FDI and ODI all initiated in 2011, thus the process of RMB internationalization is quite short. RII is calculated from the first quarter of 2010.
} 
rapidly. And in 2011, the RMB internationalization index kept on going, especially the index of second quarter showed a larger increase than that of the first quarter. In the past few eight quarters, the RMB internationalization index rose from 0.02 to 0.45 , which was an increase of 21.5 times, reflecting international community and international economic entities' considerable degree of recognition of the performance of RMB functioning as an international currency.

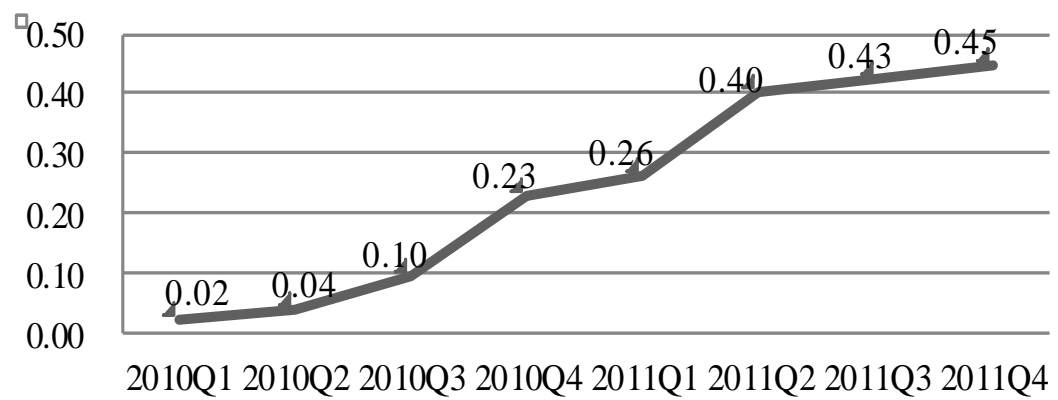

Figure 2. The RMB Internationalization Index.

\section{Structural Analysis of RII}

So far, proportion of RMB foreign exchange reserves in global foreign exchange reserves is less than $1 \%$. The main reason for the rapid increase of the RMB internationalization index is that the RMB plays an increasingly important pricing and payment role in trade and financial transactions.

As shown in figure 3, the proportion of RMB being used in international trade settlement rose $145 \%$ in each quarter in 2010. Though the growth rate of this proportion fell greatly in 2011 compared with 2010 level, this proportion still showed the $15.62 \%$ average increase.

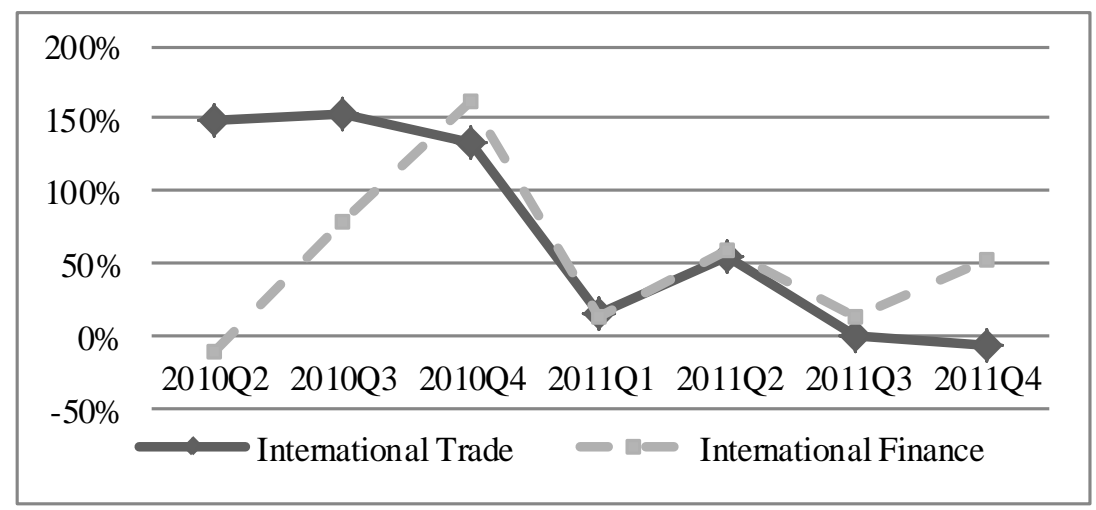

Figure 3. the weighted growth rate of RMB pricing and payment function parameter Note: see figure 1 for a breakdown of the indicator.

Since financial crisis with the down-turn economy and low demands of China's imports, the 2011 America and European's trades among the China's total trade amount dropped from $12.6 \%$ and $16.4 \%$. China's foreign trade structure has changed a lot and the multinational tendency has strengthened. ASEAN and BRICKs have become the more and more important trade partners of China with the ratio among China's trade amount rising from 10.3\% and 8\% respectively. Under such background, out of concerns around the exchange rate risk brought by devaluation and volatility of USD and JPY, China launched the cross border trade RMB settlement. According to the statistics from People's Bank of China, cross border trades settled by RMB in bank industry 
has accumulated to 2090 billion Yuan, increasing 3.1 times of 506.41 billion Yuan in 2010. The ratio of settlement by RMB amount to the total trade amount in China reaches $8.9 \%$, a great rise comparing to $2.5 \%$ in 2010. (Figure 4)

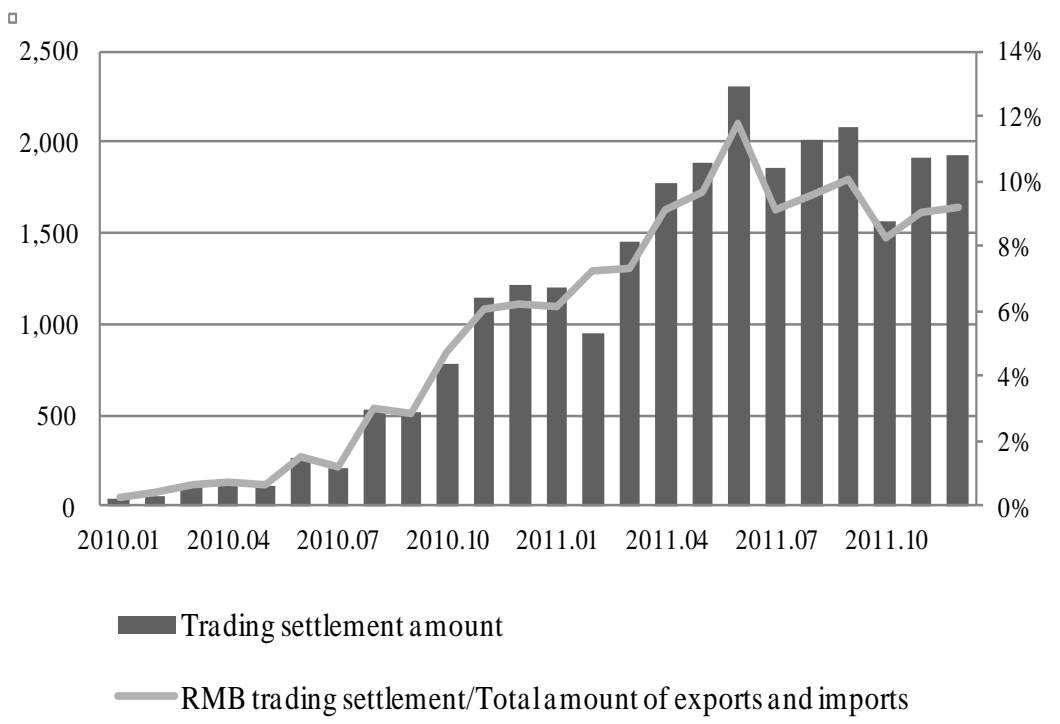

Figure 4. Cross border trade settlement by RMB monthly data (Unit: 0.1 billion) DATA SourCE: PEOPLE's BANK OF CHINA, MiNISTRY OF COMMERCE.

In 2010, the use of RMB in international financial transactions expanded rapidly, and the growth rate of the proportion of these transactions peaked at $161 \%$ in the last quarter. Thereafter, the proportion began to fall, with a characteristic of seasonal fluctuation. The growth rate of his proportion reached $52.27 \%$ in the last quarter of 2011, and the annualized growth rate was 34.68\%.

With regard to international financial pricing and payment function of the RMB, because Chinese government carried out the policy of RMB FDI and ODI, the scale of RMB direct investment is too small which is almost negligible. Those which have a greater impact on the change of this function are RMB international bonds and RMB offshore credit. As shown in Figure 5, the global proportion of RMB offshore credit, RMB bonds and notes all had a rapid growth, peaking at a growth rate of $104 \%$ and $202 \%$ respectively in the last quarter of 2010. In 2011, the growth rate in the first quarter began to fall, picked up in the second quarter, reversed again in the third quarter to around $10 \%$. In the last quarter, the issuance amount of RMB offshore bonds and notes decreased quickly by $45 \%$, thus reducing their proportion by $33 \%$. To compare, the proportion of RMB offshore credit increased at a stable pace in 2011, and the average growth rate of each quarter reached $26 \%$.

In order to objectively evaluate the gap of the level of internationalization between RMB and major currencies, internationalization indexes of the dolor, the euro, the yen, and the pound are compiled(Figure 6). According to degree of internationalization of currency, the rankings are the dolor, the euro, the yen, and the pound.

Compared with the year of 2010, the International monetary function of Euro and Sterling has been reduced significantly due to the holding back of the European sovereign debt crisis. Most of the capital outflow from Europe has chosen U.S. dollar as a temporary safe haven, which has increased the market demand for U.S. 
dollar; therefore the international index of U.S. dollar is raised. After the earthquake and tsunami strike to Japan in March 2011, huge amount of Japanese Yen funds have been withdrawn by paying off the post-disaster reconstruction, at the meantime considerable capital has also been transferred abroad for new investment opportunities. Therefore the scale of the trade settlements and financial transactions by Japanese Yen has increased substantially since, increased to an annualized pace over $5 \%$.

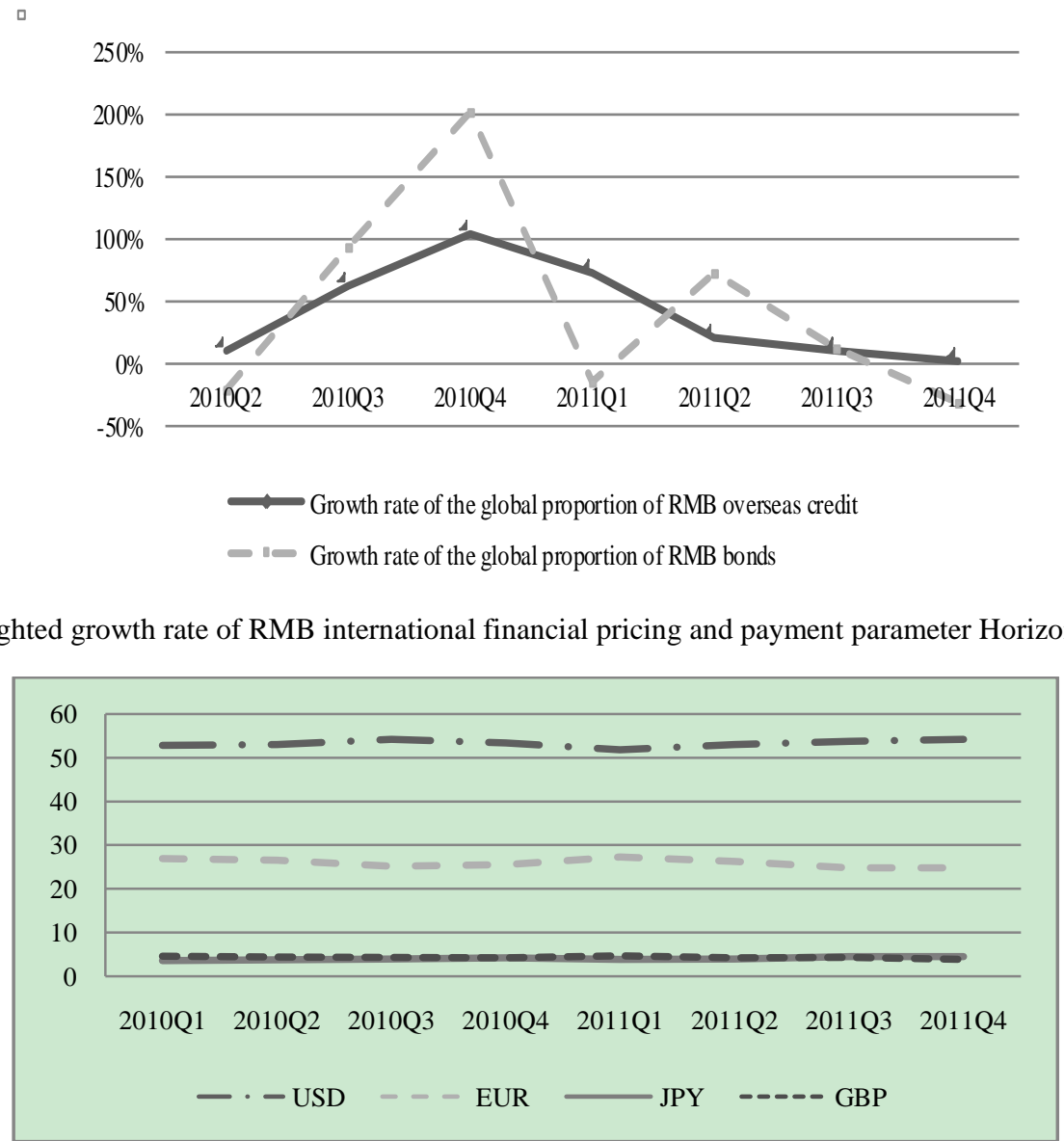

Figure 5. The weighted growth rate of RMB international financial pricing and payment parameter Horizontal analysis of RII

Figure 6. The internationalization indexes of world's major currencies.

Up to the fourth quarter in 2011, RII is only 0.45. There is a big gap of internationalization between RMB and the dollar, the euro, the yen and the pound. In fact, performance of RMB has great similarities with the yen in the early stage of internationalization of 1970s. Although the internationalization of the yen has been processed over 40 years, its internationalization level is still low. Compared with the target 15\%-20\%of proportion of JPY foreign exchange reserves in global foreign exchange reserves, the internationalization of the yen is not ideal. It can be seen from the Table 3 that although there has been almost forty years of internationalization of the yen, its internationalization index is still 4.03 on average. Therefore, the history of internationalization of the yen shows that internationalization of RMB will also be a long-run process, and its realization needs long-term vision and unremitting effort.

Acting as international reserves is one of the three major functions of the international currency, and the status of a currency in foreign reserves is the most straightforward reflection of its level of internationalization. Therefore, people tend to use the proportion of a currency in global foreign exchange reserves to simply 
describe its level of internationalization. In the modern credit monetary system, the value of money is the value of credit. Only when a currency is widely used as store of value, can illustrate that the credit value of this currency receives widespread recognition by international community, and this currency realizes internationalization. As shown in Table 14, the global proportion of the dollar, euro, yen and pound as foreign exchange reserves is $62.12 \%, 25.04 \%, 3.71 \%$ and $3.88 \%$ respectively, which are broadly similar to the internationalization index of these currencies calculated by us. In a sense, this also provides evidence for the scientific and practical nature of the currency internationalization index compiled by us.

Table 3

The global proportion of world's major currencies as foreign exchange reserves (\%)

\begin{tabular}{|l|l|}
\hline Currency & Global proportion as foreign exchange reserve \\
\hline USD & 62.12 \\
\hline EUR & 25.04 \\
\hline JPY & 3.71 \\
\hline GBP & 3.88 \\
\hline
\end{tabular}

Data Source: IMF COFER.

\section{Conclusions}

(1) Strong economic power and the trading status of "world manufacturer" are the economic foundation of the Internationalization of Chinese Currency. And the reform of International Monetary System in the post-financial crisis era has opened up a new favorable path.

(2) The major functions of international currency are pricing or account settlement, financial transactions and serving as an international reserve currency. The purpose of compiling RII is to reflect the international usages of RMB in the aforesaid three aspects.

(3) The compilation method of the index reflects the functions of international currency and the dynamic development of global international currency, providing international society with a convenient and objective method for the evaluation of Internationalization of Chinese Currency.

(4) RMB Internationalization Index stood at 0.45 in 2011 and it has grown 21.5-fold in the past two years. The international monetary function of RMB has gain a preliminary recognition from the international community, benefiting from RMB trade settlement and the establishment of offshore RMB market encouraged by Chinese government. Through a series of financial system reform, the scope for RMB to perform its duties and functions has extended gradually.

(5) RMB enjoys less than one percent share in the international reserves and there is great disparity in the internationalization of RMB compared with other major currencies.

(6) Maintaining stable economic growth, promoting market reforms of interest rates and increasing the openness of the capital market are the decisive factors of the success of the internationalization of RMB.

\section{References}

Arthur, Kroeber, “The Chinese Yuan Grows up Slowly: Fact and Fiction about China’s Currency Internationalization”, New America Foundation, Mar 2011.

Benjamin J. Cohen, “The Future of Sterling as an International Currency”, London: Macmillan, 1971.

Dobson, Wendy, Masson, Paul, “Will the RMB Become a World Currency?”, China Economic Review, May 2008.

Eichengreen, Barry, “The RMB as an International Currency”, Manuscript, Jan 2010. 
George S. Tavlas, "The International Use of the US Dollar: An Optimum Currency Area Perspective", The World Economy, Sep 1997.

Goldberg, L.S. and G.Tille, "Vehicle Currency Use in International Trade”, FRB of New York Staff Report No.200, 2005.

Kamps, A., “The Euro as Invoicing Currency in International Trade”, ECB Working Paper Series No.665, 2006.

Kannan Ramaswamy, K. Galen Kroeck and William Renforth, "Measuring the Degree of Internationalization of a Firm: A Comment" Journal of International Business Studies, Jan 1996.

Lee, Jong-Wha, “Will the RMB Emerge as an International Reserve Currency?” The Future Global Reserve System- an Asian Perspective, Asian Development Bank, Jun 2010.

Chen Yulu, “Report on the Internationalization of Renminbi 2012”, China Renmin University Press, 2012.

Li Daokui, Yin Xingzhong, "The International Monetary System in the Era of Post-Financial Crisis:What Policy Options Does China Have?”, Journal of Financial Research, Feb 2010. 